\title{
Duodenal xanthine oxidase (EC 1.2.3.2) and ferroxidase activities in the rat in relation to the increased iron absorption caused by peroral xylitol
}

\author{
BY MAURI M. HÄMÄLÄINEN \\ Department of Biochemistry, Institute of Dentistry, University of Turku, \\ SF-20520 Turku, Finland \\ AND KAUKO K. MÄKINEN* \\ School of Dentistry, University of Michigan, Ann Arbor, Michigan 48109, USA
}

(Received 13 November 1984 - Accepted 18 April 1985)

\begin{abstract}
1. The effect of peroral administration of xylitol on the absorption of iron and the activities of xanthine oxidase $(E C 1,2.3 .2)$ and ferroxidase in rat duodenal wall was studied.

2. Adult male rats were given the basal diet containing $200 \mathrm{~g} \mathrm{xylitol} / \mathrm{kg}$ or the same diet containing no added carbohydrates for 8 weeks. Both feeding groups comprised twelve animals.

3. Xylitol significantly increased serum and liver Fe concentrations with a concomitant, significant increase in the duodenal xanthine oxidase activities, but caused a marginal increase in the duodenal ferroxidase activities.

4. In vitro, sugar alcohols reduced the binding rate of Fe to transferrin.

5. The xylitol-induced increase of Fe absorption may involve the following mechanism: the high intraluminal xylitol concentration of the xylitol-fed rats keeps $F e$ in the form of a soluble complex for a prolonged period of time, due to the slow absorption of xylitol. The polyol-Fe complex in turn induces xanthine oxidase and ferroxidase formation.
\end{abstract}

Peroral administration of certain polyhydroxy compounds may increase iron absorption in experimental conditions. Such compounds include both sugars (e.g. fructose) and sugar alcohols (e.g. sorbitol and xylitol) (Herndon et al. 1958; Forth \& Rummel, 1973; Hämäläinen \& Mäkinen, 1983a). The mechanism of the increased Fe absorption during polyol ingestion is still under examination. An attractive explanation is the formation of complexes between the polyhydroxy system and the multivalent metal cation. The neutral or slightly alkaline $\mathrm{pH}$ value of the duodenal lumen may render a complex formation possible that would keep Fe in a soluble form which is necessary for the absorption process. However, other mechanisms for the favourable effect of xylitol on the absorption of $\mathrm{Fe}$ cannot be excluded. The influence of peroral xylitol on one particular aspect of this absorption process, i.e. the binding of $\mathrm{Fe}$ to transferrin with simultaneous oxidation of $\mathrm{Fe}^{2+}$ to the $\mathrm{Fe}^{3+}$ by the gut-wall enzyme ferroxidase, was tested in the present study. It should be noted that gut-wall ferroxidase is different from caeruloplasmin $(E C$ I I6.3. I) which functions in serum and liver in similar Fe-binding processes as ferroxidase in the gut wall (Topham, 1978). Since ferroxidase has recently been identified as xanthine oxidase (EC I.2.3.2) (Topham et al. 1981), the activity of the gut wall xanthine oxidase was also determined.

\section{EXPER IMENTAL}

\section{Animals and experimental design}

Twenty-four Long-Evans male rats were fed on an open-formula stock diet before the experimental period. The composition of the diet has been published in detail (Hämäläinen \& Mäkinen, 1983b). This diet contains ferrous fumarate $(200 \mathrm{mg} / \mathrm{kg})$ and its total $\mathrm{Fe}$

\footnotetext{
* For reprints.
} 
content is $196 \mathrm{mg} / \mathrm{kg}$. At the age of 12 weeks, the rats (weight $290-330 \mathrm{~g}$ ) were randomly divided into two groups of twelve animals. At the onset of the experimental feeding period, the normal pelleted food of the animals was replaced with a porridge-like food that consisted of water-ground stock diet mixture $(1: 1, \mathrm{w} / \mathrm{w})$. One group (control group) was given throughout the study this diet with no added carbohydrates, and the second group was given the diet containing $50 \mathrm{~g}$ xylitol $/ \mathrm{kg}$ during the first week. The level of dietary xylitol in the xylitol group was increased to $200 \mathrm{~g} / \mathrm{kg}$ at a rate of $50 \mathrm{~g} / \mathrm{kg}$ per week and maintained at $200 \mathrm{~g} / \mathrm{kg}$ diet for 5 weeks. The total feeding period was thus 8 weeks. Other details of the feeding schedule have been previously published (Hämäläinen \& Mäkinen, 1983a).

\section{Collection and treatment of organs}

At the termination of the feeding schedule the rats were killed with an overdose of diethyl ether. Serum, the left lobe of the liver and a $30 \mathrm{~mm}$ section of the duodenum (immediately following the pyloric sphincter) were collected from the rats as previously described (Hämäläinen \& Mäkinen. 1983a). The duodenum samples were carefully washed with cold saline ( $9 \mathrm{~g}$ sodium chloride/l) and homogenized for $10 \mathrm{~s}$ in $50 \mathrm{~mm}$-Tris-hydrochloride buffer, $\mathrm{pH} 7 \cdot 4$, containing $5 \mathrm{~mm}$-magnesium chloride $(100 \mathrm{mg}$ fresh organ $/ \mathrm{ml}$ buffer $)$ using an ILADO Laboratory Disperser (Model X-1020; Internationale Laboratoriums Apparate $\mathrm{GmbH}$, Dottingen, W. Germany) at $15000 \mathrm{rev} / \mathrm{min}$ and at $0^{\circ}$. The homogenates were centrifuged at $18000 \mathrm{~g}$ for $15 \mathrm{~min}$ at $4^{\circ}$. A portion of the resulting supernatant fraction was used for xanthine oxidase determination. Further centrifugation of the supernatant fractions at $50000 \mathrm{~g}$ for $2 \mathrm{~h}$ at $4^{\circ}$ resulted in supernatant fluids which were used for the ferroxidase assay; the turbidity of the cruder fraction disturbed the spectrophotometric ferroxidase determination.

\section{Chemical methods}

Serum and liver Fe levels were determined by the ferrozine method as previously described (Hämäläinen \& Mäkinen, 1983a). Ferroxidase was determined spectrophotometrically at $25^{\circ}$ according to Topham (1978) by following the change in absorbance with time at $460 \mathrm{~nm}$ where Fe(III)-transferrin complex exhibits maximal absorbancy $\left(E_{460}=2500 \mathrm{litres} / \mathrm{mol}\right.$ per $\mathrm{cm}$ ). The reaction mixture contained $0.35 \mathrm{ml} \mathrm{0.6} \mathrm{M-acetate} \mathrm{buffer}(\mathrm{pH} 6.0), 0.25 \mathrm{ml}$ aqueous apotransferrin solution $(20 \mathrm{~g} / 1), 0.30 \mathrm{ml} 0.4 \mathrm{~mm}$-ferrous ammonium sulphate and $0.10 \mathrm{ml}$ enzyme preparation. The $\mathrm{Fe}$ acceptor, human apotransferrin, was purchased from Sigma Chemical Co. (St Louis, Missouri, USA). Xanthine oxidase was determined spectrophotometrically (Roussos, 1967) by recording the increase in absorbancy at $290 \mathrm{~nm}$ on the aerobic oxidation of hypoxanthine to uric acid. The reaction mixture contained $0.10 \mathrm{ml} 1 \mathrm{M}$-glycine buffer ( $\mathrm{pH} 8 \cdot 8$ ), $0.10 \mathrm{ml}$ enzyme preparation (diluted with aqueous bovine serum albumin solution $(0.7 \mathrm{~g} / 1)), 0.05 \mathrm{ml} 0.86 \mathrm{~mm}$-hypoxanthine in $50 \mathrm{~mm}$-glycine buffer $(\mathrm{pH} 8 \cdot 8)$ and $0.75 \mathrm{ml}$ water to give the final volume to $1.0 \mathrm{ml}$. The reaction was allowed to proceed for $30 \mathrm{~min}$ at $30^{\circ}$. To obtain the enzyme units in $\mu \mathrm{mol} / \mathrm{min}$, the changes in absorbance were compared with the absorbancy given by a standard uric acid solution (0.01 mM-uric acid in 50 mM-glycine buffer ( $\mathrm{pH} \mathrm{8.8)} \mathrm{gave} \mathrm{an} \mathrm{absorbancy} \mathrm{of} 0.130$ ). Although previous studies indicated that a preincubation period is necessary for full xanthine oxidase activity (Stirpe \& Della Corte, 1969; Krenitsky \& Tuttle, 1978) we could not find any increase in the enzyme activity in the duodenal-homogenate fraction used after preincubation for $1 \mathrm{~h}$ at $37^{\circ}$. Therefore, no preincubation was used in the xanthine oxidase determinations. The protein concentrations of the duodenal homogenates were determined by the method of Lowry et al. (1951).

\section{Statistics}

Student's $t$ test was used to determine the significance of differences between means. 
Table 1. Concentrations of serum and liver iron of rats fed on the control or a xylitol diet for 8 weeks

(Mean values with their standard errors)

\begin{tabular}{|c|c|c|c|c|c|}
\hline \multirow{3}{*}{$\begin{array}{l}\text { Dietary group... } \\
\text { Tissue }\end{array}$} & \multicolumn{4}{|c|}{$\mathrm{Fe}$ concentration } & \multirow{3}{*}{$\begin{array}{l}\text { Statistical } \\
\text { significance of } \\
\text { difference }\end{array}$} \\
\hline & \multicolumn{2}{|c|}{ Control diet } & \multicolumn{2}{|c|}{ Xylitol $(200 \mathrm{~g} / \mathrm{kg}$ diet $)$} & \\
\hline & Mean & $\mathrm{SE}$ & Mean & $\mathbf{S E}$ & \\
\hline Serum $(\mu \mathrm{mol} / \mathrm{l})$ & $24 \cdot 0$ & 0.78 & $32 \cdot 1$ & 0.75 & $P<0.001$ \\
\hline $\operatorname{Liver}(\mathrm{mmol} / \mathrm{kg})^{*}$ & 2.08 & $0 \cdot 12$ & $2 \cdot 71$ & 0.14 & $P<0.01$ \\
\hline
\end{tabular}

* Fresh weight basis.
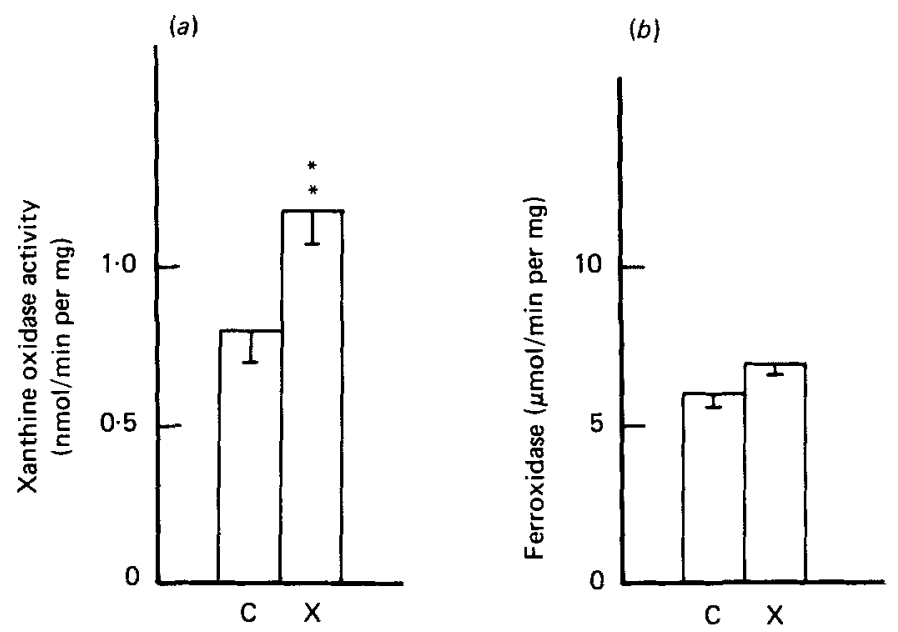

Fig. 1. Effect of peroral xylitol on the activities of $(a)$ xanthine oxidase $(E C, 1,2,3,2)$ and $(b)$ ferroxidase in the duodenal wall of Long-Evans male rats fed on the control diet (C) or a $200 \mathrm{xylitol} / \mathrm{kg}$ diet (X). The vales shown are means with their standard errors, represented by vertical bars, for twelve rats per group. ${ }^{* *} P<0.01$.

\section{RESULTS}

\section{Growth of animals}

The body-weight gains of the xylitol-fed animals were significantly $(P<0.001)$ reduced during the 8-week feeding period; the mean values of the xylitol-fed rats and the control rats were 7.8 (SE 4.5 ) g and 48.0 (SE 3.6$) \mathrm{g}$ respectively ( $n 12$ ).

\section{Fe metabolism}

Xylitol feeding significantly elevated the serum and liver Fe concentrations (Table 1). Previous studies (Hämäläinen \& Mäkinen, 1981) have shown that in spite of the reduced body-weight gains, the liver weights of xylitol-loaded rats were nearly equal to those of control animals. Consequently, the liver Fe concentration can be regarded as a true measure of $\mathrm{Fe}$ storing in these Long-Evans rats.

For the elucidation of the possible action sites of xylitol on the positive Fe balance, the binding of $\mathrm{Fe}$ to transferrin was tested with duodenum-wall preparations. As shown in Fig. 1, a small $(P<0 \cdot 1)$ increase in the duodenal ferroxidase activity was found in the xylitolfed animals. Because it has been proposed that ferroxidase and xanthine oxidase have a 
Table 2. Effect of various dietary carbohydrates on the ferroxidase activity of rat duodenum wall*

\begin{tabular}{ll}
\hline $\begin{array}{c}\text { Carbohydrate } \\
(0.33 \mathrm{M})\end{array}$ & $\begin{array}{c}\text { Ferroxidase activity } \\
(\% \text { of control }) \dagger\end{array}$ \\
\hline Glucose & $80 \cdot 9$ \\
Fructose & $111 \cdot 4$ \\
Sucrose & $85 \cdot 7$ \\
Mannitol & $90 \cdot 4$ \\
Sorbitol & $83 \cdot 8$ \\
& $90 \cdot 3$ \\
\hline
\end{tabular}

* The enzyme was obtained from the pooled homogenate of twelve animals fed on the control diet.

+ The enzyme activity determined without added carbohydrates was designated as 100 .

common origin (Topham et al. 1981), duodenal xanthine oxidase activity was also determined. The activity of this enzyme was significantly $(P<0.01)$ increased in the xylitolloaded rats (Fig. 1), this finding being in accordance with the postulated participation of intestinal xanthine oxidase in the mucosal processing of $\mathrm{Fe}$ (Topham et al. 1982). From these results it is not possible, however, to confirm the identity of ferroxidase and xanthine oxidase. Since the two enzymes were initially determined from different gut-wall-homogenate preparations, xanthine oxidase activity was afterwards tested from both fractions of gut-wall preparations obtained from rats fed on the control diet. Both fractions produced equal enzyme activity. Therefore, the type of supernatant fraction used had no effect on the previously-stated comparison between the two enzyme activities.

The in vitro effect of three sugars and three polyols on the ferroxidase activity is shown in Table 2. With the exception of fructose, all carbohydrates tested slightly inhibited the enzyme reaction. Therefore, the increase of the ferroxidase activity in the gut wall (Fig. 1) was not caused by an accelerating effect of xylitol on the enzyme reaction itself. Rather, xylitol feeding may have caused an induction of the enzyme.

\section{DISCUSSION}

Our previous studies showed that heavy xylitol loading $(200 \mathrm{~g} / \mathrm{kg}$ diet $)$ retarded the growth of Long-Evans male rats whereas lower doses $(40-50 \mathrm{~g} / \mathrm{kg}$ diet) only transiently affected growth (Hämäläinen \& Mäkinen, 1982, 1983a,b). The reduction in the body-weight gains in relation to heavy xylitol loading has been associated with slightly diminished food intake or lipolysis, or both, induced by xylitol. The present results thus confirmed these previous findings made on rats given large amounts of xylitol perorally.

Because the body Fe stores are regulated by the intestinal absorption, the mechanisms responsible for this absorption have gained considerable attention (Forth \& Rummel, 1973; Björn-Rasmussen, 1983; Charlton \& Bothwell, 1983). At the moment, however, no generally accepted mechanism for intestinal $\mathrm{Fe}$ transport exists. The traditional view includes the fairly rapid uptake of $\mathrm{Fe}^{2+}$ into mucosal cells. This passage through the mucosal surface is greatly aided by dietary $\mathrm{Fe}$ chelates and reducing agents, i.e. ascorbic acid, citric acid and fructose, which keep Fe in a suitably soluble form. These chelates include the straightchain polyols, sorbitol and xylitol (Herndon et al. 1958; Hämäläinen \& Mäkinen, 1983a). In the mucosal cell, $\mathrm{Fe}$ is either bound to the storing apoferritin molecule or transported with mucosal transferrin through the serosal surface to the blood stream, with considerably lower velocity than the initial mucosal uptake. In the plasma, $\mathrm{Fe}$ is bound to serum trans- 
ferrin. Newer hypotheses stress the participation of transferrin-like Fe transport proteins or Fe receptors in the initial mucosal uptake (Halliday et al. 1976; El-Shobaki \& Rummel, 1977; Huebers et al. 1983). The previously-described models of intestinal Fe transport include the binding of Fe to transferrin or to transferrin-like proteins in the intestinal lumen, in intestinal cells or in the plasma. The ferroxidase enzyme that is able to accelerate this binding in the gut wall was slightly increased in the xylitol-fed rats which were able to accumulate dietary $\mathrm{Fe}$ in the liver over their actual physiological need. The gut-wall homogenate obviously contained intracellular ferroxidase and, therefore, accelerated the intracellular Fe binding to mucosal transferrin. The possible secretion of the enzyme outside the mucosal cell to carry out the binding process cannot be ruled out, however. The slightly increased gut-wall ferroxidase activity in the xylitol group can be considered to support the idea of the participation of this enzyme in the xylitol-associated increase of Fe absorption. Ferroxidase activity has been shown to increase in Fe-deficient rats (Topham et al. 1982). In the present study, however, Fe was not a limiting nutrient. It is thus possible that high intraluminal polyol concentration kept the Fe in a suitably soluble form, enhancing $\mathrm{Fe}$ uptake to mucosal cells. The increased levels of complexed $\mathrm{Fe}$ may then induce intracellular ferroxidase formation. Such polyol complexes have been documented in the chemical literature (Angyal, 1974; Kieboom et al. 1975; Briggs et al. 1981). Dietary polyols like xylitol and sorbitol may favourably affect Fe absorption, since the relatively slow absorption process of the polyols maintains the necessary high intraluminal ligand level for prolonged periods of time. The intestinal xanthine oxidase has been suggested to participate in the mucosal processing of Fe (Topham et al. 1982). Because xylitol feeding was associated with a significant increase in gut-wall xanthine oxidase levels, it can be concluded that xylitol induced intestinal xanthine oxidase formation.

The ferroxidase and xanthine oxidase activities were determined from different fractions of gut-wall homogenate only for analytical reasons. It has been shown, however, that both enzyme activities are fractionated almost exclusively in the supernatant fraction in centrifugation of a duodenal homogenate for $1 \mathrm{~h}$ at $105000 \mathrm{~g}$ (Stirpe \& Della Corte, 1969; Topham, 1978). Accordingly, all cruder fractions of the original homogenate should exhibit identical enzyme activity (given per $\mathrm{ml}$ supernatant fluid, and supposing that inhibitors or activators occurred at equal levels in those fractions). We confirmed this with xanthine oxidase: both duodenal homogenate fractions exhibited nearly equal xanthine oxidase activity. Other marker enzyme activities were not determined, since the feeding procedure might have altered any marker enzyme activity as well. Although these experiments were carried out with human serum apotransferrin, the Fe-binding mechanisms may be assumed to be identical with transferrins from different sources.

\section{REFERENCES}

Angyal, S. J. (1974). Tetrahedron 30, 1695-1702.

Björn-Rasmussen, E. (1983). Lancet i, 914-916.

Briggs, J., Finch, P., Matulewics, M. C. \& Weigel, H. (1981). Carbohydrate Research 97, 181-188.

Chariton, R. W. \& Bothwell, T. H. (1983). Annual Review of Medicine 34, 55-68.

El-Shobaki, F. A. \& Rummel, W. (1977). Research in Experimental Medicine 171, 243-253.

Forth, W. \& Rummel, W. (1973). Physiological Reviews 53, 724-792.

Halliday, J. W., Powell, L. W. \& Mack, U. (1976). British Journal of Haematology 34, 237-250.

Hämäläinen, M. M. \& Mäkinen, K. K. (1981). Journal of Nutrition 111, 107-122.

Hämäläinen, M. M. \& Mäkinen, K. K. (1982). Journal of Nutrition 112, 1369-1378.

Hämäläinen, M. M. \& Mäkinen, K. K. (1983a). British Journal of Nutrition 50, 109-112.

Hämäläinen, M. M. \& Mäkinen, K. K. (1983b). Nutrition Research 3, 497-510.

Herndon, J. F., Rice, E. G., Tucker, R. G., Van Loon, E. J. \& Greenberg, S. M. (1958). Journal of Nutrition 64, 615-623,

Huebers, H. A., Huebers, E., Csiba, E., Rummel, W. \& Finch, C. A. (1983). Blood 61, 283-290. 
Kieboom, A. P. G., Spoormaker, T., Sinnema, A. van der Toorn, J. M. \& Van Bekkum, H. (1975). Recueil des Travaux Chimiques du Pays-Bas 94, 53-59.

Krenitsky, T. A. \& Tuttle, J. V. (1978). Archives of Biochemistry and Biophysics 185, 370-375.

Lowry, O. H., Rosebrough, N. J., Farr, A. L. \& Randall, R. J. (1951). Journal of Biological Chemistry 193, $265-275$.

Roussos, G. G. (1967). Methods in Enzymology 12A, 5-16.

Stirpe, F. \& Della Corte, E. (1969). Journal of Biological Chemistry 244, 3855-3863.

Topham, R. W. (1978). Biochemical and Biophysical Research Communications 85, 1339-1345.

Topham, R. W., Walker, M. C., Calisch, M. P. \& Williams, R. W. (1982). Biochemistry 21, 4529-4535.

Topham, R. W., Woodruff, J. H. \& Walker, M. C. (1981). Biochemistry 20, 319-324. 